\title{
Managerial and firm characteristics: Do they have an impact on export performance?
}

\author{
Jayanty Kuppusamy*, R. N. Anantharaman
}

Faculty of Business, Multimedia University (Malacca Campus), Jalan Ayer Keroh Lama, 75450, Malacca, Malaysia

\section{A RT ICLE INFO}

\section{Article history:}

Received 6 August 2018

Received in revised form

15 December 2018

Accepted 17 December 2018

\section{Keywords:}

Managerial characteristics

Firm characteristics

Export performance

\begin{abstract}
A B S T R A C T
Exporting enables firms to enter and expand their business internationally. Success in exporting is the goal of these firms. Although previous researchers have looked into managerial and firm characteristics as well as their influence on export performance, the results were mixed. In addition, most of the study has been conducted in the Western countries. The current research aims to fulfill these gaps. The objective of the study is to identify which managerial and firm characteristics have an impact on export performance. Exporting manufacturing firms have been selected as the unit of analysis. This is because the manufacturing industry plays a critical role in the Malaysian economy. The cross-sectional survey is used to collect the data and the respondents consist of executives of exporting firms. Questionnaires were sent to one thousand four hundred and thirty-nine firms and two hundred and twelve responded to the survey. Correlation analysis was used to identify the relationship between the factors tested. The results indicated that education level, size of firm and export experience of the firm has an impact on export performance. The findings provided critical input for export-related research, especially from a developing country.
\end{abstract}

(C) 2019 The Authors. Published by IASE. This is an open access article under the CC BY-NC-ND license (http://creativecommons.org/licenses/by-nc-nd/4.0/).

\section{Introduction}

Exporting has become necessary for businesses in entry case to expand at the international level. Furthermore, with the business landscape becoming more globalized, it increases the possibility of entering into international market. Benefits through exporting from an economical aspect include improvement of trade balance and employment level (Karadeniz and Göçer, 2007; Köksal, 2008). As a developing nation, the Malaysian government has put a lot of emphasis on increasing export with a focus on industrialisation introduced since the 1980's. Three major plans have been formed covering a period of thirty-five years to achieve the long-term objective. Government agencies such as Ministry of International Trade and Malaysian External Trade Development Corporation have introduced numerous policies towards increasing export. Export plays a critical role in the Malaysian economy from various perspectives such as

\footnotetext{
* Corresponding Author.

Email Address: jayanty.kuppusamy@mmu.edu.my (J. Kuppusamy) https://doi.org/10.21833/ijaas.2019.02.008

(D) Corresponding author's ORCID profile:

https://orcid.org/0000-0003-4782-9441

2313-626X/C) 2019 The Authors. Published by IASE.

This is an open access article under the CC BY-NC-ND license

(http://creativecommons.org/licenses/by-nc-nd/4.0/)
}

generating income, employment as well as skills and technology enhancement. In 2016, Malaysia was listed as the world's top 25 exporting nation. The manufacturing sector contributed around $23 \%$ of the GDP in 2017 and its sales value was RM765.8 billion. In addition, production increased by $6.1 \%$ in 2017 compared to 2016. The manufacturing sector's contribution towards export was high where it was $73.0 \%$ in 2017. In terms of employment in the manufacturing sector, the figure had increased from $16.6 \%$ in 2016 to $17.5 \%$ in 2017.

Due to the importance given to export specifically from the manufacturing sector, it is critical to focus on factors that will influence export performance. One of the areas of study is on the demographic characteristics namely managerial and firm characteristics. A number of export related study have included managerial characteristics and firm characteristics in their models. Among them are Suárez-Ortega and Álamo-Vera (2005), Wheeler et al. (2008), Sousa et al. (2008), and Stoian et al. (2011). Although earlier studies by Aaby and Slater (1989) and Katsikeas et al. (1996) only included firm characteristics and excluded managerial characteristics in their models, however the managerial characteristics have been stated to be important. Among the reasons indicated are management is the main force in the initiation, development as well the success of the export effort 
(Leonidou et al., 1998). Furthermore, according to Sousa et al. (2008) both managerial characteristics and firm characteristics are found in many studies since they have argued as vital. Nevertheless, the results have not been conclusive. In terms of education, although majority of studies have found it to have an influence on export performance, SuárezOrtega and Álamo-Vera (2005) found the relationship as weak in their study. Successful exporting companies generally have managers with oversea exposure however; Simpson and Kujawa (1974) indicated there is no link between travelling and exporting. In the case of employment experience, specifically export related experience although some studies found there is a relationship with export performance such as the study by Ibeh (2003) nevertheless; Das (1994) found the relationship to be minimal in his study. The relationship between age of firm and export performance has been reported to mix result (Wheeler et al., 2008). Brouthers and Nakos (2005) and Kaynak and Kuan (1993) on the other hand, pointed out the relationship between size of firm and export performance as a controversial issue since contradicting finding was found. Sousa et al. (2008)'s review found international experience of firm and export performance has mixed results. This indicates that there is a research gap and provide the motivation for study. Furthermore, most of the studies have been conducted in the Western countries. Sousa et al. (2008) pointed out that majority of the studies in export performance were conducted in US and Stoian et al. (2011) supported it. Wheeler et al. (2008) on the other hand concentrated on UK firms. Few researches were done in the emerging economies (Okpara and Kumbiadis, 2008) and developing countries in South East Asia (Julian and O'Cass, 2002). This is also a research gap. This study thus, focuses on managerial and firm characteristics and studies the relationship of these factors with export performance from the perspective of a developing country such as Malaysia.

\section{Export performance}

Export performance is measured in numerous ways. To date, there is no universal agreement on the conceptualization of export performance (Jalali, 2012; Lages and Lages, 2004; Sousa, 2004; Wheeler et al., 2008; Zou and Stan, 1998). Generally, the measurement of export performance can be categorized into two broad categories; objective or economic and subjective or strategic or noneconomic (Katsikeas et al., 2000). This conclusion is reached based on their meta-analysis study. Some researchers have pointed out that there should be both categories of measurement in order to have a comprehensive measure of export performance (Dimitratos et al., 2004; Katsikeas et al., 2000; Shoham et al., 2002; Sousa, 2004; Wheeler et al., 2008). Diamantopoulos and Kakkos (2007) and Sousa (2004) suggested that a single indicator should not be used in measuring export performance; instead, a multidimensional measurement is more suitable.

Some researchers (Brouthers and $\mathrm{Xu}$, 2002; Cavusgil and Zou, 1994; Lages et al., 2008; Shoham, 1998) used perceptual measurements in measuring export performance. Reasons supporting the usage of perpetual measurement are financial information is not easily obtainable, the lack of willingness in reporting it by the managers as well as the lack of specific export information (Lages et al., 2005). Using the subjective performance measurement is accepted since they are found to correlate with the objective measurement of performance (Geringer and Hebert, 1991). Common measures are sales and profit related (Katsikeas et al., 2000; Brouthers et al., 2009; Al-Hyari et al., 2012) although other modes of measurement have also been used. Piercy et al. (1998) used export sales, export profitability and export market share while Jalali (2012) used two dimensions, economic (export sales and profitability) and strategic dimension (market share and international expansion) to measure export performance. Ling-yee and Ogunmokun (2001) on the other hand used measures such as strategic export performance and export profitability. Zou et al. (1998) who based on Cavusgil and Zou's (1994) model introduced the EXPERF scale. This scale has dimensions such as financial performance, strategic export performance, and satisfaction with the export venture. The measurement of export performance by Styles (1998) was also based on Cavusgil and Zou (1994) where he measures financial performance through export sales, profitability, growth and strategic objectives' achievement. Ural (2009) also used the scale by Zou et al. (1998) since it covers critical perspective of export performance measures such as financial, strategic and satisfaction. According to Ural (2009), financial measure is necessary to identify the performance from the financial perspective such as profit and sales, while strategic measure covers whether the strategic goals of the firm have been achieved. Satisfaction looks into the attitudinal perspective of the export performance whether it is successful or not. Thus, the current study also adopts the measurement of Zou et al. (1998) since it found to be a broad based measurement of export performance.

\section{Managerial characteristics}

Numerous researchers have stressed on the role of decision makers towards internationalization (Chetty, 1994; Bloodgood et al., 1996). Moon and Lee (1990) pointed out manager's age can predict export behaviour. In general, younger managers are regarded to be internationally minded than older ones. Caughey and Chetty (1994) found the rate of internationalization are faster for younger managers. Education is another factor to be associated with export behaviour (Reid, 1983). Tseng and Yu (1991) pointed out the importance of education towards export related decision while Caughey and Chetty 
(1994) found highly educated decision makers would internationalise faster. Crick and Chaudhry (1997) emphasized that managers are usually highly educated. The knowledge gained through education said to assist in utilizing and leveraging opportunities at international level and preventing threats (Zou and Stan, 1998; Julien and Ramangalahy, 2003; Brodrechtova, 2008). Cavusgil and Naor (1987) have linked education with export success while Schlegelmilch (1986) indicated export performance could be enhanced with bettereducated managers since they have more managerial knowledge and capabilities. Mavrogiannis et al. (2008) obtained a similar result. They found a link between export success and education of managers. Julien and Ramangalahy (2003) and Brodrechtova (2008) reported that education's effect on export sales, growth as well as profit is positive. Similar finding is reported on the compound evaluation of export performance. However, an earlier study by Suárez-Ortega and Álamo-Vera (2005) found although the relationship between education levels with export performance is positive, it is weak.

Overseas exposure also affects export behavior. According to Nazar and Saleem (2009) and Langes and Montgomery (2004), those who have lived abroad, worked abroad, have knowledge of foreign languages studied at school will have skills, abilities and information which will be useful since they assist in achieving a firm's goals. Another benefit obtained through travel is on the ability to build network, which can assist in acquiring useful foreign market information (Ellis, 2000; Ellis and Pecotich, 2001). Charlet and Henneberry (1991) and Leake (2000) reported executives who have travelled widely are internationally oriented in their studies of successful US agribusiness exporting organizations. Crick et al. (2000) and van Rooyen et al. (2001) studied firms in United Kingdom and South African respectively found similar findings. Simpson and Kujawa (1974) reported contradicting finding where they found there is no link between travelling and exporting.

A number of researchers found that relevant experience of top management is an important success factor in marketing at international level (Byford and Henneberry, 1996). Lopez (2007) indicated that exporting firms have managers who have greater knowledge on international issues. It is found that export experience of executives influences export propensity (Ibeh, 2003) and export intensity (Suárez-Ortega and Álamo-Vera , 2005). The relationship between export experience and export performance is found to be positive by Julien and Ramangalahy (2003) and Brodrechtova (2008). In addition, Lu and Julian (2007) have stressed that due to the international experience of managers, they are found to be achieving success in exporting. Similar finding is obtained by Williams (2011). He found the owner's previous international job experience has a critical influence on export performance. This is because through experience they would have the information and understand the challenges of foreign markets and thus it helps in managing export. However, not all researchers have obtained positive results in linking experience and export performance. Mavrogiannis et al. (2008) found that the export experience does not influence export performance. Similarly, Contractor et al. (2005) reported export experience do not influence export performance in their study of Indian and Taiwanese software industry. An earlier study by Das (1994) also mentioned the influence of managers' experience on export performance is minimal. Based on the above review, the following hypotheses are formulated:

H1: There is a relationship between age of executives and export performance.

$\mathrm{H} 2$ : There is a relationship between education level of executives and export performance.

H3: There is a relationship between overseas exposure of executives and export performance.

H4: There is a relationship between employment experience of executives and export performance.

\section{Firm characteristics}

According to Chetty (1994), firm's characteristic is important for internationalization in terms of small to medium-sized firms. Other researchers such as Bloodgood et al. (1996) and Cavusgil and Nevin (1981) supported this. The firm characteristics considered in this study includes age, size and export experience of firms. Andersson et al. (2004) who studied on Swedish firms indicated it is not a significant factor. Williams (2011) also found that age of firms has no significant relationship with exporting behavior. This result is supportive of previous study by Keng and Jiuan (1989) who found age is not a significant factor towards exporting interest when comparing younger and older firms. However, Rhee (2002) and Autio et al. (2000) who found the interest in exporting to be higher in younger firms compared to older firms reported contradicting findings. Samiee and Walters (2002) found in comparing between exporters and nonexporters, the exporters have been in business for a shorter time compared to non-exporters. On the other hand, Toften and Olsen (2003) found comparative export advantages are higher as they grow older. Similarly, Lopez (2007) reported exporters are older. They export more as they become older and this is probably because of innovations and experience they have achieved over a period of time. This finding is supported by Suárez-Ortega (2003) who indicated that younger firms are found to be lacking in terms of knowledge as well as experience. Significant positive relationship between age of firms and export sales is found by Majocchi and Zucchella (2005) and Karadeniz and Göçer (2007). Baldauf et al. (2000) reported a contradicting finding. They indicated the relationship between age of firms and export performance to be negative. According to researchers as mentioned by Cavusgil and Naor 
(1987), firm size is an important variable that influences export behaviour (Burton and Schlegelmilch, 1987; Andersson et al., 2004; Hall and Tú, 2004; Pope, 2002). However, there is inconsistency or mixed findings (Stoian et al., 2011; Williams, 2011). The difference in measurement of size is among the contributing reasons for such results. In some studies, size is measured through number of employees (Bilkey, 1978) and in others sales volume (Czinkota and Johnston, 1983). Overall, employees have more commonly used to measure size (Katsikeas, 1994; Hamill and Gregory, 1997). Chetty and Hamilton (1993) who did a meta-analysis concluded that firm size effect on export performance is mostly positive although the measurement of size differs. Earlier studies by Aaby and Slater (1989) and Zou and Stan (1998) found size of firms have influence on success and export performance. Other researchers who found positive relationship are Cavusgil and Naor (1987) and Williams (2011). Lopez (2007) also supports that size of firm influences export. Furthermore, according to earlier studies by Aaby and Slater (1989) and Katsikeas and Piercy (1993) larger firm possesses superior resource stock and due to this are considered to be more successful compared to smaller firms at international level. However, Cooper and Kleinschmidt's (1985) study found the relationship between size and intensity of export to be negative. Similar findings was reported by Bonaccorsi (1992). Different findings were observed by Czinkota and Johnston (1983) and Diamantopoulos and Inglis (1988) where they found there is no relationship.

Export experience assist firms to manage their export more effectively. Various researchers have provided the support on the importance of experience in exporting. They include Ali and Swiercz (1991) and Dominguez and Sequeira (1993). Through export experience, firms are able to understand environmental condition better and react effectively (Cavusgil and Zou, 1994; Piercy, 1981). In addition, export experience assists firms to select markets and accommodate the needs of the market through specific marketing strategy (Cavusgil and Zou, 1994). Positive relationship is reported between firm export experience and export performance by Dean et al. (2000), Dominguez and Sequeira (1993), and Lado et al. (2004). Contradicting findings where negative relationship was found by Naidu and Prasad (1994) and Brouthers and Nakos (2005). The following hypotheses are thus, formulated:

H5: There is a relationship between age of firms and export performance.

H6: There is a relationship between size of firms and export performance.

H7: There is a relationship between export experience of firms and export performance.

\section{Methodology}

The focus of the study is on the manufacturing industry. Manufacturing industry is very important to Malaysia due to its contribution towards export, gross domestic product and employment. The sampling frame is obtained from the database of Malaysian Trade Development Corporation (MATRADE). This database consist of various manufacturing industries, however only those industries that have been outlined in the Industrial Master Plan as critical industries are chosen. The Industrial Master Plan, which is at its third stage, is a long-term plan in transforming Malaysia into an industrialized nation. Twelve industries were identified in the Industrial Master Plan as critical industries towards achieving this objective. In the current study, seven industries are randomly selected from the twelve industries. They are palm oil based products, food related products, pharmaceutical products, textile and apparel, medical products, machinery and equipment and electrical and electronics. The questionnaires are sent to firms in these seven industries. The questions for measuring export performance is adopted from Zou et al. (1998). The framework of the study is presented in Fig. 1. The respondents are those who are involved in the exporting activities and consist of mainly executives. Out of one thousand four hundred and thirty nine questionnaires, two hundred and twelve are found to be usable and form the basis for analysis.

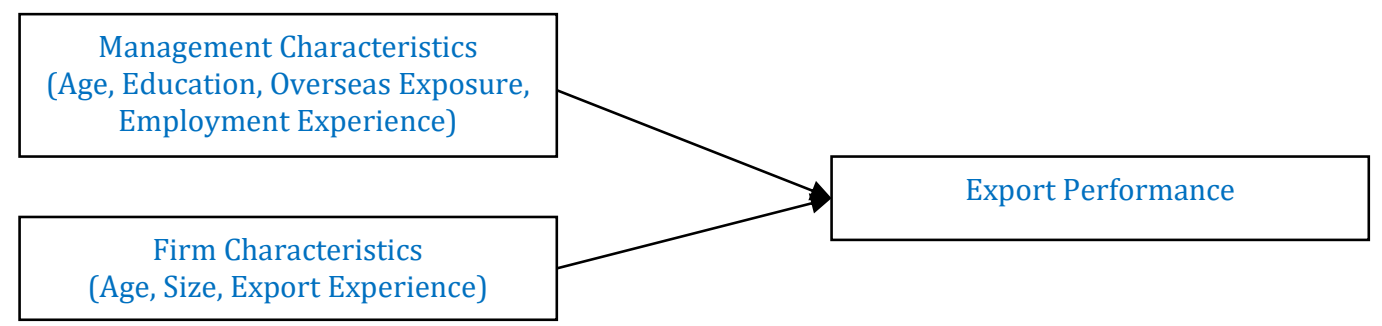

Fig. 1: Research framework

\section{Results}

Firstly, the descriptive analysis is carried out. The managerial characteristics included in this study are age of executives, education level of executives, overseas exposure and employment experience. Firm characteristics considered include age, size and export experience. It found $56 \%$ of the respondents are above 40 years of age. Those below thirty are $12.3 \%$. In terms of education, $62.6 \%$ are degree 
holders, while $7.1 \%$ have advanced degree qualifications. Respondents with diploma qualification are $27 \% .81 \%$ of the respondents have some level of overseas exposure while $87.7 \%$ have employment experience. $59.5 \%$ of the businesses are in the age group of 12 years and more while those, which were in the age group of 6 years, or less is $12.2 \%$. Businesses that have 100 to 150 employees were $34.1 \%$, while $16.6 \%$ have less than 50 employees. In terms of export experience, more than $55 \%$ of the businesses have more than 9 years of export experience while those with less than 3 years of export experience is less than $5 \%$.

Table 1 presents the correlation analysis results between managerial characteristics, firm characteristics and export performance. Among the managerial characteristics that is found to have a relationship with export, performance is education level of executives. The relationship between education level of executives and export performance is found to be significant when tested with financial performance, strategic performance and satisfaction with export performance. The Rvalues are $0.138^{*}, 0.149^{*}$ and $0.165^{*}$ respectively. $\mathrm{H} 2$ is therefore, supported. However, there is no significant relationship found in terms of age of executives, overseas exposure and employment experience of executives with all categories of export performance. The result means that $\mathrm{H} 1, \mathrm{H} 3$ and $\mathrm{H} 4$ are not supported.

In testing the relationship between firm characteristics and export performance, significant relationship were found for size and export experience. Size of firms has significant relationship with all measures of export performance, namely financial, strategic and satisfaction with export performance. The R-values are $0.137^{*}, 0.165^{*}$ and $0.137^{*}$. Similarly, export experience of firms also has significant relationship when tested with financial performance, strategic performance and satisfaction with export performance. The R-values are $0.220^{*}$, $0.153^{*}$ and $0.157^{*}$. All of them are significant at 0.05 levels. H6 and H7 are thus, supported. However, there is no relationship found between age of firm and export performance, which means H5 is not supported. The summary of results of hypotheses testing are presented in Table 2.

Table 1: Correlation analysis between managerial characteristics, firm characteristics and export performance

\begin{tabular}{|c|c|c|c|c|c|c|}
\hline \multirow[b]{2}{*}{ MC } & \multicolumn{2}{|c|}{ FM } & \multicolumn{2}{|c|}{ SP } & \multicolumn{2}{|c|}{ SAT } \\
\hline & $\mathrm{r}$ & sig & $\mathrm{r}$ & sig & $\mathrm{r}$ & sig \\
\hline Age of executives & 0.076 & 0.271 & 0.084 & 0.223 & 0.086 & 0.221 \\
\hline Education level of executives & $.138^{*}$ & 0.045 & $0.149^{*}$ & 0.031 & $0.165^{*}$ & 0.017 \\
\hline Overseas Exposure of Executives & -0.074 & 0.287 & -0.0127 & 0.066 & -0.094 & 0.173 \\
\hline $\begin{array}{l}\text { Employment Experience of Executives } \\
\qquad \text { FC }\end{array}$ & -0.051 & 0.462 & -0.052 & 0.456 & -0.124 & 0.072 \\
\hline Age of firms & 0.098 & 0.153 & 0.118 & 0.087 & 0.097 & 0.157 \\
\hline Size of firms & $0.137^{*}$ & 0.047 & $0.165^{*}$ & 0.016 & $0.137^{*}$ & 0.047 \\
\hline Export Experience of firms & $0.220^{*}$ & 0.001 & $0.153^{*}$ & 0.026 & $0.157^{*}$ & 0.023 \\
\hline
\end{tabular}

Table 2: Summary of hypotheses testing

$$
\text { Hypotheses }
$$

H1: There is a relationship between age of executives and export performance.

$\mathrm{H} 2$ : There is a relationship between education level of executives and export performance.

H3: There is a relationship between overseas exposure of executives and export performance.

H4: There is a relationship between employment experience of executives and export performance.

H5: There is a relationship between age of firms and export performance.

H6: There is a relationship between size of firms and export performance.

H7: There is a relationship between export experience of firms and export performance.

\begin{tabular}{c} 
Results \\
Not Supported \\
Supported \\
Not Supported \\
Not Supported \\
Not Supported \\
Supported \\
Supported \\
\hline
\end{tabular}

\section{Discussion}

The current study tested demographic characteristics of managers as well as firms. In terms of managerial characteristics, age, education, overseas exposure and employment experience were tested to determine whether they influence export performance. The results showed only education has influence on export performance. This result further confirms and provides support that education plays a critical part in influencing export performance. The finding is similar as found by Wheeler et al. (2008) in their review of studies of export performance done in UK. This is an important and significant finding since Malaysia is a developing nation while UK is a developed nation. This proves that education is a critical component in affecting export performance. This is probably because education at tertiary level exposes one to knowledge in various disciplines such as management, finance, marketing among others. In addition, presentation skill and research skills are also obtained through education at tertiary level. The knowledge and skills would have helped in managing the exporting activities effectively and thus, provides positive outcome through better performance. In terms of firm characteristics, both size and export experience have shown significant positive relationship with export performance. The result in terms of size of firm is similar to majority of the previous studies done such as Lopez (2007) and Williams (2011). This supported the importance of resources towards achieving success in export. This is because the larger the firm the more resources it has, thus this evidently would assist in achieving better export performance. The resource includes financial, human and physical resources, which are 
very important for manufacturing activities. Through financial resources, firms would have more funds to invest in the critical activities such as production, marketing or research and development. In terms of human resources, the ability to obtain those with expertise, experience and knowledge is higher in larger firms. Thus, with capable human resource, these large firms are able to manage their exporting activities efficiently and obtain successful export performance. Larger firms also own more sophisticated physical resources such as plant and machineries, which could assist in production efficiency. This eventually may lead to higher productivity and less wastage. All these indicate that larger firms by having more resources are able to have a better export performance. Export experience is also a valuable resource for a firm to have. The current study's finding is similar to the findings by Sousa et al. (2008) who did a review of export related studies. Experience improves firms' efficiency and the operation runs smoothly with fewer errors committed. Through experience, firms are able to identify opportunities in the international market and this would assist in their export performance. In addition, through experience, firms would be able to handle challenges in a better way. Experience also would prevent organizations from making errors in decision-making. Therefore, experience would influence the achievement of better export performance.

\section{Conclusion}

Exporting activity is encouraged by the government because it can benefit a nation economically. Furthermore, through exporting firms can develop and progress at the international level. A number of studies have incorporated demographic characteristics of managers and firms as part of the determinants of export performance; however, findings have been mixed and thus provided the motivation for this study. The results of the study provide important insights in relation to export performance from the perspectives of managerial and firm characteristics. In addition, the findings of the study indicated further support to the existing literature in the area of export performance specifically from a developing nation. One of the critical finding is the importance of education. The current study provides the evidence on the need to have systematic and relevant education system. Stoian et al. (2011) pointed out in their study in Spain on the need to have international business education and training programmes in schools and high educational institution such as at the university level. In addition, even in workplace, training programme tailored to provide expertise in international business environment should be increased and policy makers should consider this for the development of international business. Among the training areas highlighted are languages and cultures. Therefore, policy makers and government agencies should look into the demographic characteristics of managers in providing assistance and incentives for the purpose of increasing export. Both soft and technical skills are necessary to ensure they are able to manage the export activity. Promotion on types of assistance and incentives should be made to ensure those firms in need are able to know about the schemes and incentives and take advantage of them.

From the firm perspectives, it is found that both size and export experience have influence on export performance. The current study further provides support to the existing literature on the importance of size of firms and export experience. Therefore, it is very important firms have adequate resources to operate in international market since it is more risky compared to domestic market. Businesses should assess their resources. Businesses that have the capability to export but are short of funds should be given priority in getting the necessary funds. In addition, those who have no experience but are interested in export activities can be given training to recognize opportunities, exposed to the required competencies so that the firms would not face much of a problem in starting export operations. Policy makers and the relevant government agencies should look into the types of assistance and incentive and the criteria of the selection of firms to receive them. On the other hand, firms should be proactive in utilizing various incentives and programmes introduced by the government to encourage and intensify exporting activities. The limitation of the study is on the sample size and the inclusion of only manufacturing industry. Future study may look into increasing the sample size and consider more industries, specifically the service-oriented industries. In addition, a comparative study can be considered between industries.

\section{Compliance with ethical standards}

\section{Conflict of interest}

The authors declare that they have no conflict of interest.

\section{References}

Aaby NE and Slater SE (1989). Management influence on export performance: A review of the empirical literature. International Marketing Review, 6(4): 7-26. https://doi.org/10.1108/EUM0000000001516

Al-Hyari K, Al-Weshah G, and Alnsour M (2012). Barriers to internationalisation in SMEs: Evidence from Jordan. Marketing Intelligence and Planning, 30(2): 188-211. https://doi.org/10.1108/02634501211211975

Ali A and Swiercz PM (1991). Firm size and export behaviour: Lesson from the Midwest. Journal of Small Business Management, 29(2): 71-83.

Andersson S, Gabrielsson J, and Wictor I (2004). International activities in small firms: Examining factors influencing the internationalization and export growth of small firms. Canadian Journal of Administrative Science, 21(1): 22-31. https://doi.org/10.1111/j.1936-4490.2004.tb00320.x 
Autio E, Sapienza HJ, and Almeida JG (2000). Effects of age at entry, knowledge intensity, and imitability on international growth. Academy of Management Journal, 43(5): 909-24.

Baldauf A, Cravens, DW, and Wagner U (2000). Examining determinants of export performance in small open economies. Journal of World Business, 35(1): 61-79. https://doi.org/10.1016/S1090-9516(99)00034-6

Bilkey W (1978). An attempted integration of the literature on the export behaviours of firms. Journal of International Business Studies, 9(1): 34-46.

https://doi.org/10.1057/palgrave.jibs.8490649

Bloodgood JM, Sapienza HJ, and Almeida JG (1996). The internationalization of new high-potential U.S. ventures: Antecedents and outcomes. Entrepreneurship and Theory and Practice, 20(4): 61-76.

https://doi.org/10.1177/104225879602000405

Bonaccorsi A (1992). On the relationship between firm size and export intensity. Journal of International Business Studies, 23(4): 605-635.

https://doi.org/10.1057/palgrave.jibs.8490280

Brodrechtova Y (2008). Determinants of export marketing strategies of forest products companies in the context of transition-The case of Slovakia. Forest Policy and Economics, 10(7-8): 450-459.

https://doi.org/10.1016/j.forpol.2007.12.004

Brouthers LE and Nakos G (2005). The role of systematic international market selection on small firms' export performance. Journal of Small Business Management, 43(4): 363-381.

Brouthers LE and Xu K (2002). Product stereotypes, strategy and performance satisfaction: The case of Chinese exporters. Journal of International Business Studies, 33(4): 657-677. https://doi.org/10.1057/palgrave.jibs.8491038

Brouthers LE, Nakos G, Hadjimarcou J, and Brouthers KD (2009). Key factors for successful export performance for small firms. Journal of International Marketing, 17(3): 21-38. https://doi.org/10.1509/jimk.17.3.21

Burton FN and Schlegelmilch BB (1987). Profile analysis of nonexporters versus exporters grouped by export involvement. Management International Review, 27(1): 38-49.

Byford L and Henneberry D (1996). Export decisions of food processing firms in Kansas, Missouri, and Oklahoma. Agribusiness, 12(3): 247-264.

https://doi.org/10.1002/(SICI)1520-

6297(199605/06)12:3<247::AID-AGR5>3.0.C0;2-0

Caughey M and Chetty S (1994). Pre-export behaviour of small manufacturing firms in New Zealand. International Small Business Journal, 12(3): 62-68.

https://doi.org/10.1177/0266242694123006

Cavusgil ST and Naor J (1987). Firm and management characteristics as discriminators of: export marketing activity. Journal of Business Research, 15(3): 221-235.

https://doi.org/10.1016/0148-2963(87)90025-7

Cavusgil ST and Nevin JR (1981). Internal determinants of export marketing behaviour: An empirical investigation. Journal of Marketing Research, 18(1): 114-119. https://doi.org/10.1177/002224378101800114

Cavusgil ST and Zou S (1994). Marketing strategy-performance relationship: An investigation of the empirical link in export market ventures. Journal of Marketing, 58(1): 1-21. https://doi.org/10.1177/002224299405800101

Charlet B and Henneberry D (1991). Oklahoma's value-added agricultural export industry an analysis of export market activities. Journal of International Food and Agribusiness Marketing, 3(3): 55-81. https://doi.org/10.1300/J047v03n03_04

Chetty SK (1994). International trade performance of New Zealand manufacturing: An industry and enterprise-level study. Ph.D. Dissertation, University of Canterbury, New Zealand.

Chetty SK and Hamilton RT (1993). Firm-level determinants of export performance: A meta-analysis. International Marketing Review, 10(3): 26-34.

https://doi.org/10.1108/02651339310040643

Contractor FJ, Hsu CC, and Kundu SK (2005). Explaining export performance: A comparative study of international new ventures in Indian and Taiwanese software industry. Journal of Management International Review, 45(1): 83-110.

Cooper RG and Kleinschmidt E (1985). The impact of export strategy on export sales performance. Journal of International Business Studies, 16(1): 37-56. https://doi.org/10.1057/palgrave.jibs.8490441

Crick D and Chaudhry S (1997). Small businesses' motives for exporting: The effect of internationalization. Journal of Marketing Practice, 3(3): 156-170. https://doi.org/10.1108/EUM0000000004340

Crick D, Chaudhry S, and Batstone S (2000). Revising the concentration versus spreading debate as a successful export growth strategy: The case of UK SMEs exporting agriculturalrelated products. Entrepreneurship and Regional Development, 12(1): 49-67. https://doi.org/10.1080/089856200283081

Czinkota MR and Johnston WJ (1983). Exporting: Does sales volume make a difference?. Journal of International Business Studies, 14(1): 147-153.

https://doi.org/10.1057/palgrave.jibs.8490513

Das M (1994). Successful and unsuccessful exporters from developing countries: Some preliminary findings. European Journal of Marketing, 28(12): 19-33. https://doi.org/10.1108/03090569410074237

Dean DL, Mengüç B, and Myers CP (2000). Revising firm characteristics, strategy, and export performance relationship: A survey of the literature and an investigation of New Zealand small manufacturing firms. Industrial Marketing Management, 29(5): 461-477.

https://doi.org/10.1016/S0019-8501(99)00085-1

Diamantopoulos A and Inglis K (1988). Identifying differences between high and low-involvement exporters. International Marketing Review, 5(2): 52-60. https://doi.org/10.1108/eb008352

Diamantopoulos A and Kakkos N (2007). Managerial assessment of export performance: Conceptual framework and empirical illustration. Journal of International Marketing, 15(3): 1-31. https://doi.org/10.1509/jimk.15.3.1

Dimitratos P, Lioukas S, and Carter S (2004). The relationship between entrepreneurship and international performance: The importance of domestic environment. International Business Review, 13(1): 19-41. https://doi.org/10.1016/j.ibusrev.2003.08.001

Dominguez LV and Sequeira CG (1993). Determinants of LDC exporters' performance: A cross-national study. Journal of International Business Studies, 24(1): 19-40. https://doi.org/10.1057/palgrave.jibs.8490223

Ellis P (2000). Social ties and foreign market entry. Journal of International Business Studies, 31(3): 443-469. https://doi.org/10.1057/palgrave.jibs.8490916

Ellis P and Pecotich A (2001). Social factors influencing export initiation in small and medium-sized enterprises. Journal of Marketing Research, 38(1): 119-130. https://doi.org/10.1509/jmkr.38.1.119.18825

Geringer J and Hebert L (1991). Measuring performance of international joint ventures. Journal of International Business Studies, 22(2): 249-263. https://doi.org/10.1057/palgrave.jibs.8490302

Hall G and Tú C (2004). Internationalization and size, age and profitability in the United Kingdom. In: Dana LP (Ed.), 
Handbook of research on international entrepreneurship: 596-613. Edward Elgar, Cheltenham, UK. https://doi.org/10.4337/9781845420512.00042

Hamill J and Gregory K (1997). Internet marketing in the internationalisation of UK SMEs. Journal of Marketing Management, 13(1-3): 9-28.

https://doi.org/10.1080/0267257X.1997.9964456

Ibeh KI (2003). On the internal drivers of export performance among Nigerian firms: Empirical findings and implications. Management Decision, 41(3): 217-225.

https://doi.org/10.1108/00251740310469404

Jalali SJ (2012). Environmental determinants, entrepreneurial orientation and export performance: Empirical evidence from Iran. Serbian Journal of Management, 7(2): 245-255. https://doi.org/10.5937/sjm7-1687

Julian CC and O'Cass A (2002). Examining the internal-external determinants of international joint venture (IJV) marketing performance in Thailand. Australian Marketing Journal, 10(2): $55-71$.

https://doi.org/10.1016/S1441-3582(02)70150-X

Julien PA and Ramangalahy CH (2003). Competitive strategy and performance of exporting SMEs: An empirical investigation of the impact of their export information search and competencies. Journal of Entrepreneurial Theory and Practice, 27(3): 227-245.

https://doi.org/10.1111/1540-8520.t01-1-00002

Karadeniz EE and Göçer K (2007). Internationalization of small firms: A case study of Turkish small-and medium-sized enterprises. European Business Review, 19(5): 387-403. https://doi.org/10.1108/09555340710818978

Katsikeas CS (1994). Export competitive advantages: The relevance of firm characteristics. International Marketing Review, 11(3): 33-53.

https://doi.org/10.1108/02651339410067049

Katsikeas CS and Piercy NF (1993). Long-term export stimuli and firm characteristics in a European LDC. Journal of International Marketing, 1(3): 23-47.

https://doi.org/10.1177/1069031X9300100303

Katsikeas CS, Leonidou LC, and Morgan NA (2000). Firm-level export performance assessment: Review, evaluation, and development. Journal of the Academy of Marketing Science, 28(4): 493-511.

https://doi.org/10.1177/0092070300284003

Katsikeas CS, Piercy NF, and Ioannidis C (1996). Determinants of export performance in a European context. European Journal of Marketing, 30(6): 6-35.

https://doi.org/10.1108/03090569610121656

Kaynak E and Kuan WKY (1993). Environment, strategy, structure, and performance in the context of export activity: An empirical study of Taiwanese manufacturing firms. Journal of Business Research, 27(1): 33-49. https://doi.org/10.1016/0148-2963(93)90014-G

Keng KA and Jiuan TS (1989). Differences between small and medium-sized exporting and non-exporting firms: Nature or nurture. International Marketing Review 6(4): 27-40. https://doi.org/10.1108/EUM0000000001517

Köksal MH (2008). How export-marketing research affects company export performance: Evidence from Turkish companies. Marketing Intelligence and Planning, 26(4): 416430.

https://doi.org/10.1108/02634500810879313

Lado N, Martínez-Ros E, and Valenzuela A (2004). Identifying successful marketing strategies by export regional destination. International Marketing Review, 21(6): 573-597. https://doi.org/10.1108/02651330410568024

Lages LF and Lages CR (2004). The STEP scale: A measure of short-term export performance improvement. Journal of International Marketing, 12(1): 36-56. https://doi.org/10.1509/jimk.12.1.36.25647
Lages LF, Jap SD, and Griffith D (2008). The role of past performance in export venture: A short-term reactive approach. Journal of International Business Studies, 39(2): 304-325.

https://doi.org/10.1057/palgrave.jibs.8400339

Lages LF, Lages C, and Lages CR (2005). Bringing export performance metrics into annual reports: The APEV scale and the PERFEX scorecard. Journal of International Marketing, 13(3): 79-104.

https://doi.org/10.1509/jimk.13.3.79

Langes LF and Montgomery DB (2004). Export performance as an antecedent of export commitment and marketing strategy adaption: Evidence from small and medium-sized exporters. European Journal of Marketing, 38(90/10): 1186-1214.

Leake LL (2000). Good listener: International customers served by insightful pork integrator. Agri Marketing, 38(7): 78-81.

Leonidou LC, Katsikeas CS, and Piercy NF (1998). Identifying managerial influences on exporting: Past research and future directions. Journal of International Marketing, 6(2): 74-102. https://doi.org/10.1177/1069031X9800600209

Ling-yee L and Ogunmokun GO (2001). Effect of export financing resources and supply-chain skills on export competitive advantages: Implications for superior export performance. Journal of World Business, 36(3): 260-279. https://doi.org/10.1016/S1090-9516(01)00055-4

Lopez NV (2007). Export barriers and strategic grouping. Journal of Global Marketing, 20(2-3): 17-29. https://doi.org/10.1300/J042v20n02_03

Lu NV and Julian CC (2007). The internet and export marketing performance: The empirical link in export market ventures. Asia Pacific Journal of Marketing Logistic, 19(2): 127-144. https://doi.org/10.1108/13555850710738480

Majocchi A and Zucchella A (2005). Internationalization and performance findings from a set of Italian SMEs. International Small Business Journal, 21(3): 249-268. https://doi.org/10.1177/02662426030213001

Mavrogiannis M, Bourlakis MA, Dawson PJ and Ness MR (2008). Assessing export performance in the Greek food and beverage industry: An integrated structural equation model approach. British Food Journal, 110(7): 638-654. https://doi.org/10.1108/00070700810887130

Moon J and Lee H (1990). On the internal correlates of the export stage development: An empirical investigation in the Korean electronics industry. International Marketing Review, 7(5): 16-26. https://doi.org/10.1108/EUM0000000001532

Naidu GM and Prasad VK (1994). Predictors of export strategy and performance of small- and medium-sized firms. Journal of Business Research, 31(2/3): 107-115. https://doi.org/10.1016/0148-2963(94)90075-2

Nazar MS and Saleem HM (2009). Firm-level determinants of export performance. International Business and Economics Research Journal, 8(2): 105-112.

Okpara JO and Kumbiadis N. (2008). SMEs export orientation: Evidence from a developing economy. International Review of Business Research Paper, 4(5):109-119.

Piercy N (1981). Company internationalization active and reactive exporting. European Journal of Marketing, 15(3): 26-40. https://doi.org/10.1108/EUM0000000004876

Piercy NF, Kaleka A, and Katsikeas CS (1998). Sources of competitive advantage in high performing export companies. Journal of World Business, 33(4): 378-393. https://doi.org/10.1016/S1090-9516(99)80081-9

Pope RA (2002). Why small firms export: Another look. Journal of Small Business Management, 40(1): 17-26. 
Reid S (1983). Firm internationalization, transaction costs and strategic choice. International Marketing Review, 1(2): 44-56. https://doi.org/10.1108/eb008251

Rhee HJ (2002). An exploratory examination of propensity and performance in new venture internationalization. New England Journal of Entrepreneurship, 5(1): 51-66. https://doi.org/10.1108/NEJE-05-01-2002-B005

Samiee S and Walters PGP (2002). Export education: Perceptions of sporadic and regular exporting firms. International Marketing Review, 19(1): 80-97.

https://doi.org/10.1108/02651330210419742

Schlegelmilch BB (1986). Can export performance be explained by attitudinal differences?. Managerial and Decision Economics, $7(4): 249-254$.

https://doi.org/10.1002/mde.4090070406

Shoham A (1998). Export performance: A conceptualization and empirical assessment. Journal of International Marketing, 6(3): 59-81.

https://doi.org/10.1177/1069031X9800600308

Shoham A, Evangelista F, and Albaum G (2002). Strategic firm type and export performance. International Marketing Review, 19(3): 236-258.

https://doi.org/10.1108/02651330210430686

Simpson CL and Kujawa D (1974). The export decision process: An empirical inquiry. Journal of International Business Studies, 5(1): 107-117. https://doi.org/10.1057/palgrave.jibs.8490815

Sousa C (2004). Export performance measurement: An evaluation of the empirical research in the literature. Academy of Marketing Science Review, 9: 1-23.

Sousa C, Martínez-López FJ, and Coelho F (2008). The determinants of export performance: A review of the research in the literature between 1998 and 2005. International Journal of Management Reviews, 10(4): 343-374. https://doi.org/10.1111/j.1468-2370.2008.00232.x

Stoian M, Rialp A, and Rialp J (2011). Export performance under the microscope: A glance through Spanish lenses. International Business Review, 20(2): 117-135. https://doi.org/10.1016/j.ibusrev.2010.07.002

Styles C (1998). Export performance measures in Australia and the United Kingdom. Journal of International Marketing, 6(3): 12-36.

https://doi.org/10.1177/1069031X9800600306
Suárez-Ortega SM and Álamo-Vera FR (2005). SMES' internationalization: Firms and managerial factors. International Journal of Entrepreneurial Behaviour and Research, 11(4): 258-279.

https://doi.org/10.1108/13552550510603298

Suárez-Ortega SM (2003). Export barriers insights from small and medium-sized firms. International Small Business Journal, 21(4): 403-419. https://doi.org/10.1177/02662426030214002

Toften K and Olsen SO (2003). Export market information use, organizational knowledge, and firm performance: A conceptual framework. International Marketing Review, 20(1): 95-110. https://doi.org/10.1108/02651330310462284

Tseng J and Yu CM (1991). Export of industrial goods to Europe: The case of large Taiwanese firms. European Journal of Marketing, 25(9): 51-63.

https://doi.org/10.1108/EUM0000000000624

Ural $\mathrm{T}$ (2009). The effects of relationship quality on export performance: A classification of small and medium-sized Turkish exporting firms operating in single export-market ventures. European Journal of Marketing, 43(1/2): 139-168. https://doi.org/10.1108/03090560910923274

Van Rooyen CJ, Esterhuizen D, and Doyer OT (2001). Creating a chain reaction-a key to increased competitiveness in South African agribusiness. South African Journal of Economics, 69(3): 529-549.

https://doi.org/10.1111/j.1813-6982.2001.tb00024.x

Wheeler C, Ibeh K, and Dimitratos P (2008). UK export performance research: Review and implications. International Small Business Journal, 26(2): 207-239. https://doi.org/10.1177/0266242607086574

Williams DA (2011). Impact of firm size and age on the export behaviour of small locally owned firms: Fresh insights. Journal of International Entrepreneurship, 9(2): 152-174. https://doi.org/10.1007/s10843-011-0073-2

Zou S and Stan S (1998). The determinants of export performance: A review of the empirical literature between 1987 and 1997. International Marketing Review, 15(5): 333-356. https://doi.org/10.1108/02651339810236290

Zou S, Taylor CR, and Osland GE (1998). The EXPERF scale: A cross-national generalized export performance measure. Journal of International Marketing, 6(3): 37-58. https://doi.org/10.1177/1069031X9800600307 